\title{
JUSTICE-MAKING AND THE BELOVED COMMUNITY: MAPPING EMANCIPATORY LANDSCAPES AND THE PUBLIC ROLE OF THEOLOGIANS AND RELIGIOUS SCHOLARS
}

\author{
Joy R Bostic \\ Case Western Reserve University \\ Cleveland, Ohio, United States \\ Visiting Professor \\ Biblical and Ancient Studies \\ University of South Africa
}

\begin{abstract}
:
This article focuses on the religious world view and organizing strategies of United States activist, Joan Southgate who, at the age of 72, mapped out and completed a three-stage, 519 mile walk to North American Underground Railroad sites. Following this 2002 walk, Southgate founded Restore Cleveland Hope (RCH) in Cleveland, Ohio, to combat racism and other social ills. In their organizing efforts, Southgate and other community members envision and work to establish a "Beloved Community" of radical inclusivity that fuses Martin Luther King Jr. 's vision of the Beloved Community with notions of community found in Toni Morrison's 1987 novel Beloved. In this article, I draw upon Southgate's mapping strategies to establish a framework in which to discuss the public role religious scholars can play in giving voice to local religious activists and practitioners by mapping, analysing, and interpreting their emancipatory efforts.
\end{abstract}

Key Words: African American Religions; Underground Railroad;

Cultural Debasement; Social Justice; Activism; Mapping

\section{Introduction}

"It was truly a gathering of the Beloved Community. The Beloved Community marching down inner city East 105th Street. All of us Freedom Seekers headed straight to our beloved "safe house.",

For Sethe it was as though the Clearing had come to her with all its heat and simmering leaves, where the voices of the women searched for the right combination, the key, the code, the sound that broke the back of words. Building voice upon voice until they found it, and when they did it was a wave of sound wide enough to sound deep water and knock the pods off chestnut trees. It broke over Sethe and she trembled like the baptized in its wash. ${ }^{2}$

At the age of 72, Joan Southgate of Cleveland, Ohio, United States embarked upon what would become a 519-mile walk, in three stages, to select, documented North American

Southgate, Joan. In Their Path 2009 Blog. http://joansouthgate.blogspot.com/2009/06/may-30.html.

Toni Morrison. Beloved: A Novel. New York: Penguin Books, 1988:261. 
Underground Railroad (UGR) sites in Ohio, Pennsylvania and Ontario. Following the 2002 walk, Southgate, along with other community members, organised and founded Restore Cleveland Hope $(\mathrm{RCH})$, an organisation whose mission it is to bring attention to and educate communities regarding the area's abolitionist past and the implications of this past for ongoing social justice work. I first encountered Southgate in 2009 when, at the age of 80, she walked 250 miles from St Catharine's, Ontario, back to Cleveland, Ohio, to 'complete the circle' of her UGR pilgrimages. On May 30 she crossed Lake Eerie from Port Stanley, Ontario, travelling into Cleveland on a route that ended in University Circle. ${ }^{3}$ The culminating ceremony of the walk took place on the lawn of the Cozad-Bates house. The Cozad-Bates house was built in 1853 by abolitionist Andrew Bates. Located at Mayfield and E. $115^{\text {th }}$ Street, it is the last pre-Civil War structure remaining in University Circle. Although the Cozad-Bates house is not an officially documented UGR site, for Southgate and the other organizers of $\mathrm{RCH}$ the house's association with area abolitionists represents the emancipatory efforts of "Americans [come] together across class, creed and color to do

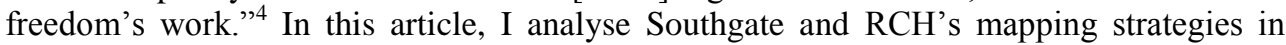
order to establish a framework in which to discuss the public role theologians and religious scholars can play within the African continent and across the African diaspora to give voice to local religious activists and practitioners by mapping, analysing and interpreting their emancipatory efforts. By intentionally drawing upon these strategies, religious scholars can further contribute to local, regional, and global efforts to bring about local and global change.

\section{Southgate's Beloved Community}

At the gathering of May 30, Southgate addressed the crowd, calling upon those assembled to embrace a common ancestry consisting of $19^{\text {th }}$ century freedom seekers and UGR conductors. At the end of her address, she gestured to the crowd and said, "Look at yourselves - I mean look at yourselves." All around her stood, sat, kneeled black, white, beige and brown bodies. They were LGBT and straight, young and old, and differentlyabled. Some wore their hair closely cropped, some had long flowing locks and others wore hijab. Southgate announced to all of us: "You are the Beloved Community." She understood this moment to be a realisation of her vision of community informed by Martin Luther King Jr.'s core social justice concepts. For King, the Beloved Community was not some naive notion of an eschatological vision of the 'Peaceable Kingdom' that could only be realised somewhere in the 'hereafter.' Rather, King understood the Beloved Community as a goal that is achievable by a "critical mass of people committed" to nonviolence, social justice and change. ${ }^{6}$ The Beloved Community has zero tolerance for systemic and interpersonal violence. While King's fight against systemic and interpersonal violence focused

\footnotetext{
3 University Circle is an area in Cleveland, Ohio that includes Case Western Reserve University, the Church of the Covenant, University Hospital, the Cleveland Museum of Art and a host of other educational, cultural and religious institutions. It is immediately surrounded by predominantly African American neighbourhoods and municipalities such as Glenville and East Cleveland.

4 Joan E Southgate and Fran Stewart. In Their Path: A Grandmother's 519-Mile Underground Railroad Walk: With Community Histories and Profiles (Solon, OH: Eagle Creek Press, 2004). See also The Restore Cleveland Hope web site (http://www.restoreclevelandhope.org/about.html).

5 Southgate, Joan. In Their Path 2009 March, programme at the Cozad-Bates House, May 30. 2009.

6 The Martin Luther King, Jr. Center for Nonviolence Social Change. www.thekingcenter.org.
} 
largely on the 'three evils' of militarism, poverty, and racism, ${ }^{7}$ his denouncement of discrimination generally and his demand for operating systems of social justice that support the personal and bodily integrity of all members of the global community opens the door for Southgate and other contemporary activists to envision and work to establish an advanced understanding of the Beloved Community. Southgate's notion of the Beloved Community involves a radical inclusivity that refuses to tolerate social, psychic, physical or political violence against the personal and bodily integrity of any member of the local or global community. This includes violence related to gender, (physical/mental and social) ability and sexuality.

\section{Sacred Geographies and Mapping the Underground Railroad}

Since the 1990s the Underground Railroad (UGR) in North America has received renewed attention as community groups, agencies, historians, and descendants of conductors and freedom seekers have attempted to identify routes, safe houses, and border crossings that are a part of its vast network. Originally these sites - out of necessity - were closely guarded secrets among abolitionists and freedom seekers alike. Historically UGR lines, connections and conductors were part of a clandestine network. ${ }^{8}$ Specific sites and routes were kept secret, for the survival of those involved depended upon concealment of their activities. ${ }^{9}$ Contemporary pilgrims, however, trying to retrace these ancestral steps seek to render public and visible the significant sites and relationships involved in these networks. Out of these networks these pilgrims map religious and cultural landscapes, meaning and identity. Such mappings (material and imaginative, past and present, individual and collective) serve as 'sacred-making' activities. For some these activities also provide new meanings for social justice work. Above all, I argue that these sacred-making endeavours are spatial practices of mapping memory for many individuals and communities seeking to recover a painful past, redefine an ambivalent present and create a hope-filled future. By identifying, interpreting and analysing such mappings and practices across the African continent and its diaspora, we as religious scholars and theologians further render these practices public and help to connect them within a larger, more collective discourse.

These spatial practices are especially significant for blacks in the United States whose ancestry has been touched by the legacy of slavery. For US blacks, cultural memory and ethnic identifications are in some ways truncated by the systematic suppression and demonisation of African ethnic and regional cultural practices and beliefs by colonisers, slave traders, slave owners and their surrogates. Being captured, enslaved and violently uprooted geographically and culturally often meant that Africans in America and their descendants had to struggle continually for a sense of space and place that would provide an authentic ground for individual and communal expression as well as validation. In this way, these African American pilgrims act as 'freedom seekers' and their pilgrimages serve as emancipatory practices in which they confront this painful legacy of physical and symbolic violence in order to reconnect with their ancestors and other members of the African diaspora.

See, for example, Martin Luther King, Jr. Where Do We Go from Here: Chaos or Community? Boston:

Beacon Press, 2010.

8 Katherine McKittrick. Demonic Grounds: Black Women and the Cartographies of Struggle.

Minneapolis: University of Minnesota Press, 2006:18.

9 Ibid. 
As a creative response to what historian of religion Charles Long describes as the 'involuntary presence'10 of Africans in North America, enslaved African Americans construct religious structures and practices that adhere to certain aspects of an African American world view rooted in African-derived cosmologies. Within these cosmologies the living and the dead commune together according to particular views of sacred time. According to these notions of time, the past and present co-exist in dynamic relationship one to another in order to impact upon the future. Thus, the dead are still speaking. It is these ancestors and spirit guides that call the living to work out the unfinished business of the past - unfinished business that can potentially lead to the formation or re-formation of African American identity.

\section{The Dead are Still Speaking: Ancestral Call as Impetus for Action}

On 2 April 2002 it was my late mother's voice that put my feet in the path. ${ }^{11}$

Years ago, Joan Southgate began walking through her Glenville neighbourhood as a matter of health. On one particular day in 2002, she started out as usual with her cat Nelson Mandela tagging along. He would always follow her at the beginning of her walk, then suddenly, drop out of sight. At the end of her walks, as Southgate turned the last corner and headed for home, Nelson would reappear and accompany her on the short stretch back to the house. On this particular walk something different occurred. This time as she turned the corner she reports hearing these words: What was it like and how can I praise them? This two-fold question then became a refrain:

What was it like and how can I praise them?

What was it like? How can I praise them?

What was it like and how can I praise them? ${ }^{12}$

Then the response, as Southgate recalls, "The answer fell into place just as I rounded the corner for home: I will take their journey and set myself free." 13

Southgate identifies the response with her own mother's voice. She states, "It was my dead mother's voice that put my feet in the path." This account is consistent with an African American sacred-social world that is inhabited by the living and the dead. Although Southgate is a member of Euclid Avenue Congregational Church and identifies herself as a Christian, she also incorporates non-Christian, African-derived concepts into her personal cosmology. Within the context of this sacred-social world, the dead remain present and are yet speaking. Family members and ancestral spirit guides serve as transcendent forces that continue to impact on the lives of the living. This sacred-social world view operates according to specific notions of time in which past, present and future co-exist in dynamic relationship one to another. In narratives such as Southgate's, it is these ancestors and spirit guides that call the living to work out the unfinished business of the past - unfinished business that continues to impact on the present. She uses the concept of 'Sankofa,' an Akan term that literally means to "go back and fetch it" to indicate work that involves a retrieval of the past. In embarking upon a pilgrimage to select UGR sites, Southgate wanted

\footnotetext{
10 Charles H Long. Significations: Signs, Symbols, and Images in the Interpretation of Religion. Aurora, CO: The Davies Group, 1999:188.

11 Southgate and Stewart. In Their Path, p. 18.

12 Ibid, p. 14.

13 Ibid. See also In Their Path. www.intheirpath.org.
} 
to experience in her own body what it might have felt like for $19^{\text {th }}$ century freedom seekers in order to set herself free from the shame and violence of her own personal past. ${ }^{14}$

In her books In Their Path (co-written with Fran Stewart) and 'Bout Time, Southgate remembers the shame she felt as a child. She was born in Syracuse, New York, six months before the market crash of 1929 that launched the Great Depression. She explains that she "grew up in the debris." Her father, Falstaff Lionel Harris, was an artist and her mother, Evelyn Claracy Harris, filled her and her siblings' days with song, story, and sound. Southgate attended Croton Elementary school. At Croton Southgate was 'happily popular.' She was smart, eager to volunteer (she describes herself as frequently being the teacher's pet) and a class leader. ${ }^{15}$ Generally, she was happy and felt included. She recalls that in some ways she even felt superior to the other children - except when the subject of slavery was covered in class. ${ }^{16}$ Southgate remarks how African American slaves were most often presented as dependent, helpless victims. She writes, “...I always felt so sad. ...I was suddenly alone and ashamed of the people I came from. It was pathetically shameful that those people, my people, could be uneducated and scared and abused. What had they done?"17

Southgate's memories of shame and pain associated with black enslaved bodies also stirred up memories of the intimate violence and threats to bodily integrity in her own life. Her mother was verbally and physically abused by her father who was also an alcoholic. Her father also beat her and her siblings. When she turned sixty suppressed memories of incest surfaced. Walking this pilgrim's journey was Southgate's own way of engaging in self-emancipatory action to confront and heal the memories of her own past. For Southgate, these walks would serve as mystical acts of prayer in which she would deeply connect with not only her personal past but a larger, collective past. This collective past and the shame and pain often associated with it are due to what religious scholar Renee Harrison refers to as the 'cultural debasement ${ }^{\prime \prime}$ of black peoples, their histories, and their religious, philosophical and artistic productions. This cultural debasement and anti-Africanist views ${ }^{19}$ helped to establish and justify the colonization of the African continent, the African slave trade, and post-colonial and post-emancipation institutions of segregation and economic exploitation (such as apartheid and Jim Crow). Out of these conflicted histories Africans and people of African descent have maintained and constructed religious practices that have enabled them to navigate and reconfigure their respective socio-historical landscapes. Scholars of black religion are crucial co-travellers with these communities as we identify and analyze these reconfigured landscapes.

Once Southgate announced her intention to travel to UGR sites, her own co-travellers family members, neighbours, and members of religious and community groups - came together to form an organising committee. Committee members assisted Southgate as she mapped out the UGR sites she would visit. They also helped to arrange lodging, transportation and educational talks along the selected routes. Southgate's dining room remains

\footnotetext{
Southgate, Joan. Interview by Joy R Bostic, 4 November 2009.

Joan E Southgate. 'Bout Time. Solon, Ohio: Eagle Creek Press, 2007:28-29.

Southgate and Stewart. In Their Path, p. 13.

Ibid, 12-14.

18 Renee K Harrison. Enslaved Women and the Art of Resistance in Antebellum America. Palgrave Macmillan, 2009.

19 Dianne M Stewart. Three Eyes for the Journey: African Dimensions of the Jamaican Religious Experience. New York: Oxford University Press, 2005.
} 
decorated with some of the maps, signs and other artifacts that mark the space in which she, neighbours, family members and friends organised her first series of trips. In planning her itinerary, Southgate selected cities and locales to which she had personal and familial connections. For example, the Ohio River Valley where her first walk began was not only significant because of key UGR sites along its borders, but also because her husband Robert was from Cincinnati. Yellow Springs was an important stop because her daughter attended Antioch College there. St. Catharine's was the home of her maternal grandmother. These sites were also significant because of their associations with freedom seekers and conductors such as John Parker, John Rankin and Harriett Tubman. Southgate was intentional about visiting the sites associated with these 'ancestors' in order to honour them and seek their affirmation.

As she travelled to different locales, Southgate met and accepted hospitality from strangers interested in her pilgrimage. As a result, she added other sites and networks to her map. Nineteenth century conductors and freedom seekers as well as 21 st century fellow UGR enthusiasts are all co-travellers on Southgate's journey. In her mapping of these sites and her spatial practices, Southgate acknowledges that her own embodied social history is linked to the diverse social histories of the living and the dead. In our own mapping of the emancipatory practices of black people across the globe, religious scholars based in diverse locales also serve as co-travellers. We map complex itineraries that mark the significant spaces and practices that often intersect with our own social histories and intellectual commitments. The question is how we understand these diverse itineraries, social histories and scholarly commitments more thoroughly and more effectively in relation to one another. Joan Southgate's mapping practices and Thomas Tweed's approach to the theory of religion may provide some clues. Southgate's mapping of contemporary UGR pilgrimages and her spatial practices involve the three themes of Thomas Tweed's approach mobility, relationality, and positionality. ${ }^{20}$ For Southgate, these acts of mapping are dynamic spatial practices that reveal the important relationships of pilgrims and freedom seekers. In the course of these spatial practices, she establishes, re-confirms or reconfigures these relationships from the vantage point of her own position within her sacredsocial world.

\section{Mappings, Borders and Crossings}

The markers of Southgate's pilgrimage involve the navigation of significant borders, crossings and bridges. The three major points of entry and culmination in the three-stage journey were the Ohio River Valley, the Canadian border near St Catharine's, Ontario and Port Stanley on Lake Eerie. The Ohio River was a point of contestation during the antebellum period. While freedom seekers struggled to cross the river to the free state of Ohio, the Fugitive Slave Act of 1850 made it possible for slave catchers to travel across the river and return black freedom seekers to slave owners by force. Lake Eerie and the Niagara River were also contested borders. While boats and bridges helped to transport freedom seekers further north, slave catchers remained a constant threat. In traversing these borders, crossings and bridges, Southgate believes that she has been called to take this journey to not only praise the ancestors but to achieve an emancipation of the self from the pain and shame of intimate violence. Literary theorist Katherine Clay Bassard states that

20 See Thomas A Tweed. Crossing and Dwelling. A Theory of Religion. Cambridge, Mass.: Harvard University Press, 2006. 
physical movement in space serves as a necessary symbolic movement for identity transformation. By engaging in these spatial practices for the initial purpose of giving 'praise' to freedom seeking and conductor-ancestors, Southgate is also transformed. By way of these spatial practices, she identifies with the pain, disorientation and fear; and, ultimately, with the hope of her ancestors. As she participates in her sacred social world by way of these spatial practices, Southgate also accesses the sacred power mediated by intergenerational relationships which contribute to the re-making of her own identity. Her walk across the Peace Bridge into Ontario is indicative of her communal and family ties as well as the role the ancestors play on this journey.

"Walking across the Peace Bridge into Canada was glorious because it was three generations of women - my daughter Teci, my 7-year-old granddaughter Helena and me.

Actually, there must have been four. I'm sure my mother was there." 21

Thus, her journey begins as a personal endeavour involving selected sites and locales related to particular and individual associations. As a freedom seeker, however, she also seeks to bring others along this sacred-social continuum. As a peace pilgrim, walking for Southgate is prayer. It is a spatial practice imbued with implications for communal commitment and social justice. She and others are creating and re-creating sacred-social spaces where ancestors walked. Following her pilgrimage, the echoing charge of the initial refrain she hears when her dead mother's voice sets her feet on the path, changes from the singular 'I' to the plural 'we.'

\section{What was it like?}

How can we praise them? Proudly tell their stories.

The walking is done. But the journey continues. ${ }^{22}$

As scholars of black religion, we often engage in individual research projects focused on particular locales. Even though we may share our work with other scholars within our geographical regions or even internationally, we don't often collaborate in ways that document, explore and make coherent the complex commonalities and differences that exist in black religious practices across the globe. Southgate's social practices and Tweed's theories provide a framework for how we might map borders, crossings, bridges and points of relationality and contestation related to sites of religious practice, social reconstructions and political resistance across historical, ethnic and cultural divides.

\section{Sacred Geographies as Assemblages and Mediators of Diverse Social Histories}

As a part of her collaborations and educational efforts regarding the importance of the history of the Underground Railroad in Northeast Ohio, Southgate founded Restore Cleveland Hope. The organising work itself arose of out organic, fluid and dynamic processes. Committee members who worked with Southgate for many hours in her dining room, along with an increasing number of other local activists, have assisted her in the development of $\mathrm{RCH}$. The organising efforts of the group have focused primarily upon reclaiming the Cozad-Bates house, with its own history as contested space and setting the space aside for intergenerational, educational and social justice organising. Through the organizing work of $\mathrm{RCH}$ and other community stakeholders, the Cozad-Bates house was designated a landmark site and the house is being renovated for public use. Southgate's 2009 walk, which

21 Southgate and Stewart. In Their Path, p. 254.

$22 \quad$ Ibid, p. 261. 
represented a completion of the Sankofa 'circle,' was for the purpose of raising funds for the restoration. Her walk from St. Catherine's, Ontario, to Cleveland was her way of returning to the circle - University Circle, that is. Her goal this time was focused more specifically on promoting her new local mission - the preservation of the Cozad-Bates house and raising awareness on UGR networks in Cleveland and Northeast Ohio. The organization has also held a series of "Beloved Community Dialogues" in which participants engage with the stories of UGR conductors and freedom seekers from the perspective of their own social histories.

The geographical space of the Cozad-Bates house, other places associated with the UGR and the layers of memories represented by the social histories of UGR conductors, freedom seekers and contemporary pilgrims take on significant meaning. These geographies might be represented by the image of a collage or assemblages consisting of the interplay between the personal and the collective in which pilgrims select and invest landmarks of the past - products of highly energized interaction of history and memory with new meaning and associations. These sites become places worked over by imagination, constantly taking on new configurations; and serve as anchors and frames in the search for identity and assertion of birthright and belonging. This identity construction and reclamation takes place for Southgate within the context of an African diasporic cosmological world view or a sacred-social world. This cosmology or world view continues to influence African American religious perspectives and practices. Southgate's account is consistent with an African-derived, sacred-social world that is inhabited by the living and the dead. Consistent with this world view, pilgrims such as Southgate imbue physical and geographical sites identified with 'the ancestors' with layers of imaginative re-constructions that include the memories and the re-membering of the dead who, as active members of the sacred-social community, continue to communicate with and empower freedom seekers. In order to render these reconstructions public as coherent landmarks, scholars of black religion might explore how these sacred spaces act, as what Jualynne Dodson refers to, as "constructed assemblages of shared awareness that articulate a three-dimensional symbolic expression of the body of knowledge that undergirds [black peoples'] comprehensions about life and being in the world" ${ }^{, 23}$ within specific locales and, comparatively, across geographical and cultural borders.

Southgate's journey begins as a personal endeavour with selected sites and locales based on personal associations. As a freedom seeker, however, she also seeks to bring others along on this emancipatory journey. In founding $\mathrm{RCH}$, she chose the name 'Hope' to emphasize Cleveland's role in the UGR network as a point of exit for freedom seekers who travelled by ferry across Lake Eerie into Canada. The port in Cleveland was referred to as Hope and Port Stanley on the other side of the Canadian border was known as God be Praised. Likewise, by way of this abolitionist past and the symbolic representation of the Cozad-Bates house, Southgate and RCH declared University Circle to be 'sacred ground.' Southgate's notion of sacred ground signals to us that her conception of community involves a greater depth of complexity than Martin Luther King, Jr.'s articulation. Here, I want to explore Toni Morrison's representation of community in her 1987 novel Beloved as a way of understanding the deeper contours of Southgate's vision.

23 Jualynne E Dodson and José Millet Batista, Sacred Spaces and Religious Traditions in Oriente Cuba. Albuquerque: University of New Mexico Press, 2008:62. 


\section{The Beloved Community and Subverting an Anti-Africanist Paradigm}

In Beloved, Toni Morrison presents a narrative centered around Sethe - a freedom seeker who left the Sweet Home plantation in Kentucky to travel north with her three children while pregnant with her fourth child. She travelled to the Cincinnati area to reside with Baby Suggs, her husband Halle's mother. Baby Suggs was an 'unchurched preacher' and a former slave who had also fled north across the Ohio River. She took up residence in a house at 124 Bluestone Road in the Cincinnati, Ohio, area. Located on the outlying borders of the city, 124 served a vital role within the local African American community as well as for freedom seekers passing through on their way to points farther north. The house became a site for clandestine communications as well as for social and cultural exchange. Baby Suggs functioned as a prophet and mediator of African American culture for many in the surrounding community.

In Morrison's novel, the title character 'Beloved' is believed to be the ghost of the child Sethe killed. She had been 'haunting' the house at 124 Bluestone Road over the course of years. Now she appears as a young woman. Beloved's 'haunting' of the family has caused Sethe and her daughter Denver to become largely ostracised and the house at 124, which had once served as a vital thoroughfare of communal exchange and support, became strange and alien, a place to be avoided, feared, a target of ridicule and the subject of great suspicion. When Sethe's former slave master and his posse descended upon her two years after she had arrived, no one in the community alerted her or intervened. The tragic result was that Sethe believed she had no other option than to kill her child rather than have her returned to slavery. This time, however, when the conflict over Beloved's return had reached its breaking point, thirty women in the community took note and gathered together to confront the ghost not only of Sethe's past but of their collective past. The women were led by Ella who was the first to determine that Sethe needed 'rescuing' from this ghost that was 'whipping' her. Morrison describes the scene as the women came together.

Some brought what they could and what they believed would work, stuffed in apron pockets, strung around their necks, lying in the space between their breasts. Others brought Christian faith - as shield and sword. Most brought a little of both. They had no idea what they would do once they got there. They just started out, walked down Bluestone Road and came together at the agreed-upon time. A woman dropped to her knees. Half of the others did likewise.... ${ }^{24}$

It is with the collective gathering of diverse women employing hybrid forms of black religious symbols and practices that the house at124 Bluestone Road once again serves as a site that mediates cross-diasporic religious and emancipatory discourses and practices. Within this Beloved Community, participants are co-travellers whose diverse social histories are understood to be linked and intertwined in ways that subvert the anti-Africanist paradigm. For scholars of black religion, subverting these prevailing anti-Africanist assumptions involves grappling with many questions. These questions include: How do we as African and African diasporic scholars continue to uncover and reclaim emancipatory and healing traditions within diverse cultural contexts that, because of the history of antiAfricanism and cultural debasement, have become marginalized and deemed suspect? How do we respond to the crisis that results from the myriad forms of symbolic and actual violence experienced by dark-skinned people of African descent? How might our collaborative efforts enable us to think about what strategies are needed to address these 
issues both globally and locally? Joan Southgate and the community of women that gather to resolve Sethe's crisis at the end of Toni Morrison's novel might provide some strategies that we can employ.

First of all, efforts to combat the effects of colonialism, the slave trade, and the cultural debasement of African and African diasporic religion and culture requires recognition and identification of the unfinished business of our past and the ongoing ways in which the dead are still speaking. Our collective work is to recover, analyse and re-articulate the practices and social histories of black people across generational divides. In so doing, we engage in a religio-cultural mapping of sites and moorings - spaces in which black identity has been formed and re-formed within contexts of racial oppression and exploitation. As scholars, we engage in public discourses whereby emancipatory black and African cultural productions are rendered visible and validated. In our documentation and analyses we reveal how these sites serve as assemblages of African and African diasporic expression and practice saturated with historical and symbolic meaning by the communities with which we engage. In order to address the challenges facing people of African descent across the globe, however, it may not be enough for us to continue to focus only on specific locales as individual scholars. I would like to challenge us as scholars working to bring about social change, to consider the ways in which we might further engage one another in collective efforts to reveal the complex landscapes of African and African-derived emancipatory religious practices and the ways in which African and African diasporic social histories are connected. For it is within the context of diverse stories and sounds that we as religious scholars and activists contribute to a collective embodiment of the Beloved Community, that is, we find the right, key, note, chord, combinations of sound, story and song that can break the back of systemic oppression and violence so that the personal and bodily integrity of black people and all people can be supported and affirmed on a global scale and across complex differences.

\section{BIBLIOGRAPHY}

Dodson, Jualynne E, and José Millet Batista 2008. Sacred Spaces and Religious Traditions in Oriente Cuba. Albuquerque: University of New Mexico Press.

Harrison, Renee K 2009. Enslaved Women and the Art of Resistance in Antebellum America. New York: Palgrave Macmillan.

King, Martin Luther, Coretta Scott King, and Vincent Harding 2010. Where Do We Go from Here: Chaos or Community? Boston: Beacon Press.

Long, Charles H 1999. Significations: Signs, Symbols, and Images in the Interpretation of Religion. Aurora, CO: The Davies Group.

McKittrick, Katherine 2006. Demonic Grounds: Black Women and the Cartographies of Struggle. Minneapolis: University of Minnesota Press.

Morrison, Toni 2004. Beloved: A Novel. New York: Vintage International.

Southgate, Joan E 2007. 'Bout Time. Solon, Ohio: Eagle Creek Press.

Southgate, Joan E, and Fran Stewart 2004. In Their Path: A Grandmother's 519-Mile

Underground Railroad Walk: With Community Histories and Profiles. Solon,

$\mathrm{OH}$ : Eagle Creek Press.

Stewart, Dianne M 2005. Three Eyes for the Journey: African Dimensions of the Jamaican Religious Experience. New York: Oxford University Press.

Tweed, Thomas A 2006. Crossing and Dwelling a Theory of Religion.

Cambridge, Mass.: Harvard University Press. 